Andrzej Niewiadomski

Uniwersytet

Marii Curie-Skłodowskiej

w Lublinie

\title{
Dlaczego nie powstanie historia literatury polskiej ostatnich trzydziestu lat?
}

\section{Abstract \\ Why the History of Polish Literature of the Last Thirty Years Will Never Be Written?}

The article deals with attempts by literary critics and literary historians to order Polish literature of the last thirty years. It points to the low operational value of the categories and terms used by researchers when trying to define the most important features of literature of that period. Periodization that pinpoints the literary breakthrough to the year 1989 cannot be such a sorting order, nor can it be the category of literary generation or the distinction between modernist and postmodern literature in Poland. An attempt to create the history of literature on the thirtieth anniversary of the political breakthrough encounters significant difficulties connected mainly with the fact that there is no identifiable closing event for that period. The first steps towards a reliable description should be, although it is a very difficult task, to give up used terminology, diversify research reflection and introduce a broader historical perspective going back beyond 1989 .

Słowa kluczowe: literatura najnowsza, modernizm, postmodernizm, pokolenie literackie, przełom w literaturze, periodyzacja, krytyka literacka

Keywords: recent literature, modernism, postmodernism, literary generation, breakthrough in literature, periodization, literary criticism 
Odpowiedź na pytanie postawione w tytule wydaje się prosta i taka w istocie jest, nie sposób jednak nie zauważyć pewnego kłopotu wiążącego się z jej udzieleniem, nie sposób też pominąć faktu, że pytanie to prowokuje - jak często bywa, gdy padają stwierdzenia eksponujące niemożność - rozważania o możliwych alternatywach dla koncepcji funkcjonowania tego wycinka polskiej literatury, który obejmuje ostatnie trzydzieści lat. Wspomniana trudność polega na niechęci do znęcania się nad nieuleczalną predylekcją badaczy polonistów do porządkowania materii literackiej w myśl mocno zakorzenionych w tradycji dyscypliny założeń o istotnej zależności nowych stylistyk czy propozycji programowych od rytmu zmian społeczno-politycznych. To, co było usprawiedliwione w latach dziewięćdziesiątych, jako rezultat powszechnych oczekiwań, z dzisiejszej perspektywy jawi się jako cezura wymuszona i nieznajdująca odzwierciedlenia w ,przełomowych” faktach. Każda kolejna dekada po roku 1989 była systematycznie podsumowywana jako swoiste zamknięcie „nowego” etapu, ale żadna z tych charakterystyk nie przysporzyła nam argumentów na rzecz w miarę jednolitego, spójnego ujęcia zjawisk literackich zaistniałych po tej dacie ${ }^{1}$. Dzieje się tak zapewne dlatego, że nie ma zgody w sprawie kryteriów, jakie miałyby być podstawowymi wyznacznikami nowych tendencji i propozycji, a różne głośne terminy krytycznoliterackie, którymi posługiwano się w ciągu tych trzech dekad, powoli znajdują swoje miejsce już tylko w historii krytyki literackiej i sporów o kształt literatury, toczonych zresztą w drugiej połowie tego okresu ze znacznie mniejszą energią niż na początku ostatniego dziesięciolecia XX wieku. Jeszcze inną kwestią jest chaos cząstkowych propozycji krytycznych nieukładających się w spójne narracje konstruowane na bazie w miarę przejrzystych i konsekwentnie stosowanych kryteriów. Jeśli nawet moglibyśmy wskazać na ,prywatne”, konsekwentnie budowane opowieści o literaturze, to są one albo (jak w przypadku koncepcji krytyków czy badaczy starszych pokoleń) marginalizowane, albo też nie mogą osiągnąć takiego stopnia wyrazistości, by można było mówić o polaryzacji różnych stanowisk, które nadają ton (poza sporami polityczno-środowiskowymi) debacie o literaturze najnowszej.

Jak zatem napisać historię literatury trzydziestolecia, gdy to trzydziestolecie nie stanowi żadnej zamkniętej całości? Koniec drugiej dekady XXI wieku nie obfituje w sygnały końca estetyk, formacji czy nurtów literackich. Gdyby nawet takowe się pojawiły, obawiam się, że mielibyśmy spory kłopot z ich rozpoznaniem, w obliczu panującego chaosu aksjologicznego i sztucznie narzucanych hierarchii. Fakt ten jawi się jako oczywisty, mniej oczywiste natomiast jest uparte forsowanie cezury roku 1989 jako daty granicznej. Pomijając już kłopot terminologiczny (niepostrzeżenie „literatura najnowsza” stała się,

1 Pisałem na ten temat w artykule Dwudziestolecie versus dwudziestolecie. O przypadkach poezji najnowszej z perspektywy historyka literatury, „Teksty Drugie” 2013, nr 3. 
po trzydziestu latach, już nie literaturą najnowszą, a wkrótce nawet nie literaturą „nową"), nie możemy przejść do porządku dziennego nad brakiem istotnych wydarzeń literackich związanych $\mathrm{z}$ tą datą, jak również z datami sąsiednimi.

Nie chciałbym tu wyważać otwartych drzwi, nie po raz pierwszy negacja tej cezury i jej okolic jako momentu objawienia się nowych tendencji literackich została wszak sformułowana. Takie głosy dały się słyszeć w całkiem nieodległej od wspomnianej daty perspektywie drugiej połowy lat dziewięćdziesiątych XX wieku i, jak myślę, celnie wskazywały słabe strony kształtującej się periodyzacji. Jak pisał Krzysztof Uniłowski:

Uczciwość każe jednak zauważyć, że pierwszą bodaj po wojnie polityczną cezurą, która nie okazała się akuszerem nowych trendów literackich, były lata 1980-1981, Dziś trudniej już byłoby znaleźć rzeczników hipotezy, podług której z perspektywy czasu rok 1989 okaże się dla historii literatury równie istotny co $1918^{2}$.

Diagnoza badacza sformułowana w drugiej połowie lat dziewięćdziesiątych (pomijając fakt, że rok 1918 też nie okazał się aż tak istotny w perspektywie historii literatury) wydaje się intuicyjnie słuszna, podobnie zresztą jak sformułowane przez niego już wtedy wstępne wnioski dotyczące „przełomu” i wiele rozpoznań szczegółowych. Jednocześnie konstatował on co następuje:

W pewnej sferze doniosłości roku 1989 nie sposób wszakże kwestionować. Wraz z Polską Ludową zniknęło wiele, po części skompromitowanych, instytucji życia literackiego, czemu towarzyszyła praca nad stworzeniem nowej infrastruktury ${ }^{3}$.

Nastąpiło zatem swojego rodzaju rozdzielenie słabego oddziaływania „nowej” literatury jako propozycji radykalnie odmiennej od dotychczasowych konwencji i socjologii życia literackiego, zdeterminowanego przez generalną zmianę polityczną. W następnej dekadzie Joanna Orska pisała wręcz o „pułapce” przełomowości, w którą - chcąc nie chcąc - wpadamy nawet wtedy, kiedy próbujemy odżegnać się od dyskursu o cezurach zwiastujących „nowe":

Kwestia przełomu zostaje przez wszystkich badaczy ostatniej dekady uznana za zasadniczą lub choćby wartą podniesienia - bez względu na perspektywę czasową, z jakiej zagadnienie to jest rozpatrywane i bez względu na moc rozróżniającą, jaką przyznaje się samemu pojęciu. Żaden z wyżej wymienionych [badaczy - przyp. A.N.] nie zdecydował się na przewrócenie szachownicy. Krytycy i teoretycy, choć

2 K. Uniłowski, Skądinąd, Bytom 1998, s. 5.

3 Ibidem, s. 6. 
nawet świadomi, że problem przełomu wiąże się ze swoistą retoryką, każdorazowo i, chciałoby się powiedzieć, rytualnie właśnie tej retoryce się oddająa ${ }^{4}$.

Jednocześnie Orska zwracała uwagę na kontrast między narzekaniami na brak „nowości” a całkiem sporą liczbą krytycznych świadectw wskazujących na wagę (szczególnie) poezji powstającej po roku 1989 i - przy wszystkich zastrzeżeniach podnoszonych wobec tej daty - skłaniała się jednak ku mówieniu (subtelniej) o ,przemianie” polegającej na „odświeżeniu priorytetowego modelu poezji polskiej”, odchodzącej od „uniwersalności i jednoczesności wszystkich sensów dwudziestowiecznej, polskiej, epifanijnej liryki wysokiego modernizmu"s.

Można więc było, generalnie negując wywrotowy potencjał literatury debiutantów lat dziewięćdziesiątych, uznawać (przynajmniej chwilową) przydatność cezury roku 1989 i podobnie można było, mniej uwagi poświęcając społecznym aspektom domniemanej literackiej zmiany, sygnalizować, że jednak dokonała się ona w przestrzeni „nowych”, niezależnych głosów.

Rzecz nie w tym, by wywracać stolik, którego już wywrócić się nie da w odniesieniu do poręcznych periodyzacji (jesteśmy na nie skazani, tak jak jesteśmy od wielu lat skazani na mówienie o dwudziestoleciu 1918-1939), rzecz w tym, by ciągle mieć świadomość mechaniczności interesującej nas cezury, która pozwala (a może tylko pozwalała?) przejść do zagadnień literatury bieżącej, zasygnalizować, że interesuje nas ona w pewnej izolacji od zjawisk wcześniejszych, a może raczej, że interesuje nas jej sytuacja w zmienionych warunkach społeczno-politycznych, ekonomicznych, w kontekście kultury masowej i rewolucji cyfrowo-informatycznej. Innymi słowy, wskazując na nowość, zwracamy najczęściej uwagę na przesunięcia zainteresowań (sfera tematów i kontekstów) lub na przesunięcia akcentów w obrębie językowej materii tekstu literackiego, warunkowane inną postawą wobec zmieniającej się rzeczywistości. Mniej interesuje nas mimo wszystko (i interesowała w ciągu minionego trzydziestolecia) obecność integralnych wizji twórczych, mogących rywalizować $\mathrm{z}$ utrwalonymi w tradycji literatury XX-wiecznej trybami artykułowania zagadnień stricte artystycznych. Modyfikacje - z pewnego punktu widzenia, tropiącego niuanse aktualizujących ujęć na przykład poetyckich - są bardzo istotne, ale z oddalenia lat dwudziestu pozostają wyłącznie reinterpretacjami zagadnień i poetyk modernistycznych lub, łagodniej rzecz ujmując, sugestia ich rewolucyjności z ostatniej dekady minionego wieku

4 J. Orska, Liryczne narracje. Nowe tendencje w poezji polskiej 1989-2006, Kraków 2006, s. 12. Warto na marginesie zauważyć, że dwudziestowieczna poezja polska „wysokiego modernizmu" nie poddaje się definiowaniu jedynie w perspektywie epifaniczności, nie mówiąc już o częstym jej funkcjonowaniu na pograniczu różnych nowoczesnych estetyk.

Ibidem, s. 20. 
była w dużej mierze rezultatem posługiwania się językiem krytycznym, który „okazał się nieprzygotowany do przyswajania i interpretowania »nowych« i na nowo odnalezionych języków poetyckich wcale nie tak odległych od tradycji modernizmu polskiego i światowego (zwłaszcza krajów anglosaskich)"' Wydaje się przy tym, że refleksja dotycząca poezji w większym stopniu ujawniała chęć widzenia tej dziedziny twórczych zatrudnień jako przestrzeni dla „przełomowych” konceptów, niż czynił to namysł nad prozą ostatnich lat trzydziestu. Ujawniałoby to zasadniczy kłopot w procesie konstruowania przyszłej narracji historycznoliterackiej, o ile rzeczywiście ta różnica jest aż tak istotna. Konieczność synchronizacji odmiennych języków opisu łączyłaby się ponadto z potrzebą uzgodnienia stanowisk kładących nacisk na autoteliczny wymiar poezji i socjologiczne uwikłania prozy. Są to już jednak zagadnienia innego rzędu niż trudność zasadnicza: brak wyrazistych ram czasowych omawianego zjawiska.

U progu lat dziewięćdziesiątych minionego wieku oczekiwania na nowość podtrzymywała także próba wprowadzenia do dyskursu krytycznoliterackiego chętnie używanej w wieku XX kategorii pokolenia. Od tradycyjnego jej rozumienia, ustalonego w klasycznej pracy Kazimierza Wyki ${ }^{7}$ odcinała się jednak znaczna część krytyków i znakomita większość debiutujących autorów. Dążność do ich postrzegania grupowego była bardzo silna, stąd też zapewne brały się próby wprowadzenia tego pojęcia w łagodniejszej formie (,tak zwane pokolenie" w tytule książki Jarosława Klejnockiego i Jerzego Sosnowskiego ${ }^{8}$ ) czy zamiany kryterium generacyjno-literackiego na kryterium socjologiczne. Zmiana charakteryzowana jako pojawienie się pewnej grupy autorów połączonych wspólnym przeżyciem i wspólnym celem wydawała się kuszącą perspektywą, rychło jednak zorientowano się, że wszelkie próby wydobycia przeżycia pokoleniowego muszą skończyć się porażką, zaś wspólnota celu sprowadza się do działań promocyjnych. Wspominam o tych oczywistościach ze względu na tkwiący wciąż głęboko w świadomości nie tylko krytyków, ale i badaczy pewnik dotyczący istnienia generacyjnej grupy poetów, dla której tytuł czasopisma jest już tylko hasłem wywoławczym (dotyczy też często autorów w ogóle niepublikujących na łamach „bruLionu”), pozwalającym nazwać, pod nieobecność innych szyldów, procesy zachodzące w obrębie poezji po roku 1989 (znów jednak pojawia się problem, co począć z prozą, dla której nie wytworzono klucza pokoleniowego). To jedna z przyczyn upartego trwania kategorii, która nie posiada już istotnych walorów poznawczych: brak historycznoliterackiego, twardego gruntu, gdy próbujemy mówić o „nowej” literaturze.

6 J. Orska, Republika poetów. Poetyckość i polityczność w krytycznej praktyce, Kraków 2013, s. 467.

7 K. Wyka, Pokolenia literackie, Kraków 1977.

8 J. Klejnocki, J. Sosnowski, Chwilowe zawieszenie broni. O twórczości tzw. pokolenia „,bruLionu” 1986-1996, Warszawa 1996. 
Wydawałoby się, że tak jak zaproponowane przez Wykę pojmowanie „pokolenia literackiego" odchodzi w przeszłość, tak też - wraz z nim - działania mające charakter periodyzacyjny znajdą się na cenzurowanym. Jednakowoż na początku nowego wieku rozgorzały dyskusje wokół antologii Tekstylia, której autorzy obwieszczali, iż „nie ma mowy o pokoleniu” roczników siedemdziesiątych ani z socjotechnicznego, ani z krytycznego punktu widzenia ${ }^{9}$, jednocześnie - znów z braku innych kryteriów ${ }^{10}$ - próbowali jakoś zdefiniować grupę debiutujących autorów, nazywając ją również „,formacjąa” i nakładając tym samym na siebie różne pojęcia. Ważne jednak - jak myślę w owym symulowanym „manifeście” już nie generacyjnym, ale wciąż grupowym i „rocznikowym” było odwołanie do Poetyki pisarstwa historycznego Haydena White'a i przyjęcie następującego założenia: „Nie można odkryć historii literatury, takowa bowiem nie istnieje. Historię literatury można natomiast stworzyć" ${ }^{11}$. Tym samym jego twórcy uczynili pierwszy krok w kierunku przywrócenia kategorii pokolenia literackiego, co - jak się zdaje - zostało wykorzystane w procesie dookreślania cech swoistych kolejnej grupy młodych autorów, mających przy tym świadomość, że można mówić jedynie

[...] o narracyjnym potencjale tej kategorii, pozwalającym traktować ją jako pewien wzorzec mówienia o świecie. Przy czym równocześnie podkreśla się nieesencjonalny charakter pojęcia: pokolenie jako projekt tożsamościowy ma każdorazowo konstrukcyjny charakter ${ }^{12}$.

W tym właśnie duchu wypowiadali się stosunkowo niedawno autorzy antologii Zebrało się śliny, również dystansujący się od pokoleniowości, jeżeli miałaby ona być rozumiana w sposób tradycyjny, a przy okazji negujący konserwatywne porządki periodyzacyjne... i jednocześnie wprowadzający je tylnymi drzwiami, właśnie dzięki wykorzystaniu „konstrukcyjnego charakteru" wspomnianych kategorii. Tym razem grupe generacyjną bardzo luźno rozumianą (w antologii znaleźli się autorzy urodzeni pomiędzy 1978 a 1987 rokiem, a zatem także na płaszczyźnie rozważań czysto socjologicznych należący, jak się zdaje, do różnych pokoleń) miałoby spajać pojęcie „poezji zaangażowanej”, zaś jej główne cechy, odróżniające od innych nurtów, to fakt, iż:

9 Zob. P. Marecki, I. Stokfiszewski, M. Witkowski, Wszyscyśmy z White'a [w:] iidem, Tekstylia. O rocznikach siedemdziesiątych, Kraków 2002, s. 12.

10 „Chyba najtrafniejszej oceny zręczności i poręczności terminu »roczniki siedemdziesiąte « dokonał Mariusz Sieniewicz, który [...] stwierdził, że terminem tym posługujemy się najpewniej dlatego, że lepszego po prostu nikt nie wymyślił” (ibidem, s. 9).

Ibidem, s. 8 .

12 A. Artwińska, M. Fidelis, A. Mrozik, A. Zawadzka, Pożytki z „,pokolenia”. Dyskusja o ,pokoleniu” jako kategorii analitycznej, „Teksty Drugie” 2016, nr 1, s. 349. 
[...] nie jest przywiązana do konkretności żadnego pojedynczego doświadczenia i żadnej poszczególnej tożsamości. Jeśli dąży do jakiegoś rodzaju wspólnoty bądź jakąś wspólnotę tworzy, jest to nie wspólnota pewnego doświadczenia [...], tylko pewnych przekonań [...]. Jej krytyczna perspektywa wynika raczej z chęci artykulacji pewnych poglądów - i, najczęściej, pragnienia społecznej zmiany - niż z walki o uznanie bądź dążenia do ekspresji doświadczenia ${ }^{13}$.

Biorąc pod uwagę ów konstrukcyjny charakter pokoleniowości, należy zauważyć, iż nawet w takim wydaniu wpisuje się ona doskonale w zwyczaje rodzimej krytyki literackiej i funkcjonujących na jej pograniczu badań nowoczesności, inercyjnie ciążących ku staremu językowi opisu. Wielokrotnie zaś czynione zastrzeżenia są tu warunkiem wprowadzania nowych, w mniemaniu krytyki, zjawisk na zasadach podobnych do tych funkcjonujących wcześniej, co widać doskonale choćby w takiej deklaracji dotyczącej poezji o, w szerokim tego słowa rozumieniu, politycznym zapleczu:

Proces, o którym myślimy, a który nazwać można chyba zwyczajnie rosnącą popularnością wierszy zaangażowanych wśród młodych twórców i twórczyń, zintensyfikował się wyraźnie około dekady temu. Trudno określić dziś jakiś rodzaj przełomowej, dającej mu początek daty; wielu krytyków i krytyczek pozostaje sceptycznych wobec idei „przełomu” czy „zwrotu”, który miałby polityczność dla polskiej poezji odzyskać. Tym niemniej ta prosta obserwacja - że coraz więcej wierszy wikła się celowo i świadomie w ekonomiczno-społeczne i polityczne rejestry języka, że coraz częściej dyskutuje się otwarcie o polityczności młodej poezji wydaje się trudna do podważenia bądź zlekceważenia ${ }^{14}$.

Jednocześnie mamy do czynienia z innym sygnałem; autorzy antologii zwracają uwagę na to, że jej performatywna funkcja polega na wypromowaniu „najciekawszych i najistotniejszych nowych głosów w polskiej poezji”, a zatem jest to działanie niemal nieróżniące się od tradycyjnych trybów następstwa generacyjnego. Czy przeprowadzone z sukcesem? Niekoniecznie, taki język raczej zawodzi, tak jak zawodził w przypadku wszystkich ponowofalowych ,pokoleń”. Na marginesie tego zagadnienia należy zauważyć, że dyskusje o polityczności i zaangażowaniu poezji doskonale wpisują się także w rzeczywistość innego schematu krytycznej lektury nowych tekstów literackich, schematu biegunów, które miałyby celnie opisywać (znów) przede wszystkim dokonania poetyckie: najpierw funkcjonującego jako spór pomiędzy klasycystami i barbarzyńcami, później jako starcie poezji niezrozumiałej

13 P. Kaczmarski, M. Koronkiewicz, Stowo wstępne [w:] iidem, Zebrało się śliny, Stronie Śląskie 2006, s. 12.

14 Ibidem, s. 7.

15 Ibidem, s. 8. 
i zrozumiałej lub (w innym wariancie) ponowoczesnych $\mathrm{z}$ nowoczesnymi, wreszcie - w ujęciu wielu najmłodszych krytyków - jako zderzenie zaangażowania z estetyzmem. Ten ostatni spór, podobnie jak wszystkie pozostałe, wydaje się jednak pozorny, a jego podstawy często bywają negowane przez samych entuzjastów poezji politycznej w momencie, gdy sygnalizują obecność zaangażowania $\mathrm{w}$ utworach poetów debiutujących $\mathrm{w}$ latach dziewięćdziesiątych, a odczytywanych (mylnie) przez krytykę wyłącznie „w kategoriach nieustannego mnożenia znaczeń, podważania wszystkich pewników, błyskotliwej gry pastiszów, cytatów i intertekstów, nakierowanej głównie na »literacką " przyjemność”16. Tym samym podważona zostaje, mimo podkreślania różnic i polemicznych ujęć, świeżość oferty poetów najmłodszych, a w chwili, gdy jest ona wysuwana na plan pierwszy, dyskusyjne wydaje się twierdzenie o politycznym potencjale formy wiersza autorów starszych generacji, forsowane już wcześniej, chociażby we wspomnianej książce Orskiej. Nie mówiąc o tym, że sprawa nieśmiało, ale konsekwentnie podnoszonego przesilenia zwiastującego polityczność literatury jako żywo nasuwa na myśl schemat odnoszący się do konstruowanej o dekadę wcześniej paraleli dwudziestolecia międzywojennego i czasu III Rzeczpospolitej Polskiej: w pierwszej połowie XX wieku mieliśmy wszak (w podręcznikowej narracji) do czynienia z reakcją na estetyzujące $\mathrm{i}$ „wyzwalające” propozycje, jakie pojawiły się w latach dwudziestych w postaci zaangażowania choćby poetów Drugiej Awangardy. Owszem, paralela to odległa i nie do końca trafiona, trudno jednak oprzeć się wrażeniu, że w krytycznej nieświadomości zbiorowej tkwią jakieś archetypiczne wzorce „porządkowania doświadczeń”.

Jeszcze inną kwestią, która - zamiast stanowić pole poszukiwań możliwych kategorii opisu ostatniego trzydziestolecia - stała się, jak myślę, istotną przeszkodą na drodze do klarowniejszego widzenia tego okresu, jest zamieszanie związane z procedurami użycia terminów „modernizm” i „,postmodernizm" w stosunku do zjawisk zachodzących w literaturze po roku 1989. Wiąże się to, o czym warto raz jeszcze wspomnieć, z nieprzepracowaniem modernistycznych obsesji zarówno przez samą literaturę, jak i przez badania literackie - szczególnie w stosunku do drugiej połowy XX wieku. Jeśli, jak zauważał niegdyś Uniłowski, brakuje aparatu pojęciowego pozwalającego „ująć całość zjawiska”, nie możemy mówić ani o dopełnieniu, ani o zrozumieniu modernizmu ${ }^{17}$. Tym bardziej trudno będzie wyrokować na temat polskiego postmodernizmu, ponieważ w grę wchodzi tu nie tylko zaplecze teoretyczne (to zostało przyswojone), lecz także jego niejasny status w obrębie literackiej współczesności. Postmodernizm, najpierw gorliwie egzorcyzmowany lub widziany wyłącznie przez pryzmat hasła nothing matters, anything goes, następ-

16 P. Kaczmarski, M. Koronkiewicz, Góra i Kopyt - wspólne punkty odniesienia [w:] iidem, Zebrało się śliny, s. 59.

17 Zob. K. Uniłowski, op.cit., s. 17-22. 
nie awansowany do rangi wiodącego klucza, otwierającego znaczne obszary współczesnej poezji i prozy (niemniej pozostawiającego z niczym czytelników nieświadomych zmiany i niechętnych wobec nieprzejrzystości tekstu), ale też później rozczarowujący jako narzędzie swoistej inżynierii społeczno-literackiej, w końcu zaś powracający do łask już w innej postaci, jako wyrafinowane narzędzie kreowania dyskursu politycznego, wciąż wydaje się mało uchwytny. Być może dzieje się tak z wyartykułowanego przez Przemysława Czaplińskiego powodu niemożności zaakceptowania przez polską literaturę (w tym wypadku prozę) rzeczywistości ponowoczesnej przy takiej samej niemożności powrotu do przednowoczesnych konwencji i trybów objaśniania czy odkrywania świata, a być może powody są zupełnie inne. Bez względu na to, czy uznamy proponowaną przez badacza kategorię późnej nowoczesności za trafną, nie ulega wątpliwości, że w ciągu ostatnich trzydziestu lat mamy do czynienia z nakładaniem się na siebie różnych horyzontów ideowych i różnych strategii funkcjonowania $\mathrm{w}$ obrębie życia literackiego. W tym sensie Czapliński ma rację, pisząc, że odbijający się w prozie po roku 1989

[...] czas transformacji to epoka sprasowanej historii idei: przednowoczesne postrzeganie społeczeństwa jako wspólnoty etnicznej współistnieje z nowoczesnym jego wyobrażeniem jako organizacji celowej i ponowoczesnym jego ujmowaniem jako wspólnoty konsumentów ${ }^{18}$.

Co jednak począć ze zwiastunami ponowoczesności pojawiającym się przed kluczową z punktu widzenia obrońców „,przełomu” datą? Jak poradzić sobie z nieprzekładalną na jedną narrację, czy to literacką, czy historycznoliteracką, wielopostaciowością postmodernizmu i jego potencjałem krytycznym, niedającym się wykorzystać tylko przez jedną stronę społeczno-politycznego sporu, jako narzędzie kształtowania konkretnych postaci tożsamości rozproszonej? Jak umożliwić rzeczywistą, a nie symulowaną wymianę narracji?

Na razie dysponujemy tylko zarysami opowieści, które ani nie odnoszą się do całości literackich propozycji minionego trzydziestolecia, ani też nie przekreślają refleksji „ułatwionej”, bo bazującej na zużytych opozycjach, wstydliwie kryjących się za współczesnym instrumentarium pojęciowym. Jeśli więc chcemy, po blisko trzydziestu latach, raz jeszcze zadać pytanie, „,czy jest możliwa inna historia literatury" w odniesieniu do stosunkowo nowych zjawisk, abstrahująca od schematyzmów i uwzględniająca różne punkty widzenia, musimy, po pierwsze: przyjąć założenie, że zdołamy dowieść, iż dzieje literatury są ,zrozumiałe w tej mierze, w jakiej pozwalają uchwycić zasady swego narastania"19 , po drugie: zgodzić się z twierdzeniem, że nie wiemy wciąż, ,jak

18 P. Czapliński, Polska do wymiany. Późna nowoczesność i nasze wielkie narracje, Warszawa 2009, s. 18.

19 T. Walas, Czy jest możliwa inna historia literatury, Kraków 1993, s. 191. 
to się skończyło", i powinniśmy skoncentrować się na rewizji refleksji dotyczącej procesów ustanawiających ewentualną „zmianę”, ,przełom”, „cezurę”, wreszcie, po trzecie: zrezygnować z materiału „kanonicznego” (nieobecność kanonu, która niepostrzeżenie przeradza się w jego narracyjną postać, przy utrzymaniu dominacji jednej właściwie tylko opowieści, to kolejna bolączka badawczych poczynań), zakładając, że trzydziestoletni okres uprawnia nas do rewizji wielu pewników. Mamy bowiem do czynienia z kanonem symulowanym (lub konsekwentnym, długoletnim podtrzymywaniem „kanonu roboczego"), tak jak z symulowaną aksjologią krytyczną, polegającą na selekcjonowaniu grup poetów i prozaików wedle zasady wpisywania w tekst literacki strategii nieznajdujących potwierdzenia nie tylko w utworach o charakterze programowym, ale też znoszących się wzajemnie w obrębie dzieł tego samego autora. Może właśnie ów brak należałoby uczynić ośrodkiem refleksji na temat nowego „kanonu”, nieuwikłanego w pozorowane wartości, nieuchronnie odsyłające do zużytych kategorii i biegunów pojęciowych albo czynników koniunkturalnych ${ }^{20}$.

Jeżeli zaś mówimy w języku narratologii o historycznoliterackich opowieściach, to jednym ze sposobów ich ożywienia i uwiarygodnienia jest dopuszczenie innego typu konceptów, zbudowanych na niezapożyczonej terminologii i na aparacie pojęciowym niejako wydestylowanym z warunków lokalnej literatury oraz lokalnych dyskursów, przy czym owa lokalność nie oznacza tu marginalności; wręcz przeciwnie - dotyczy najbardziej energicznych i żywych elementów naszej literatury konfrontowanych $\mathrm{z}$ wielością innych diagnoz. Nie chodzi tu o żaden izolacjonizm, raczej należałoby raz jeszcze przemyśleć zagadnienie potencjalnej zdolności rodzimej literatury do narzucania tematów i konwencji nieoczywistych oraz nieprzystających do uproszczonych (mimo całej finezji teoretycznego zaplecza) uwarunkowań społecznych, a także nieustających procesów przekładu tychże na język form i odwrotnie. Innymi słowy, potrzebna byłaby (w maksymalistycznym wariancie) taka opowieść, która bazuje na języku pozwalającym zdystansować się również od przymusu przywoływania modernizmu-postmodernizmu jako ostatecznego punktu odniesienia dla refleksji badawczej i skoncentrować się na mechanizmach braku takiego odniesienia jako kryterium ustanawiania „kanoniczności”. Wymagałoby to jednak radykalnego wyprzedzenia horyzontu współczesności, czego oznaki w obrębie tekstów literackich są nieliczne, zaś krytyka nie jest skora ani do prorokowania, ani też do ujęć postulatywnych, poza sytuacjami, w których sfera postulatów mieści się doskonale w języku obowiązujących i aktualnych dyskursów. Poza wszystkim stanowisko takie musiałoby być oparte na

20 „Generacyjna czołówka sklecona tedy została z autorów literacko i światopoglądowo poprawnych” (K. Uniłowski, op.cit., s. 58). Wydaje się, że ta konstatacja odnosząca się do ostatniej dekady XX wieku, mogłaby zostać powtórzona, z drobnymi modyfikacjami, także w dekadach następnych. 
intuicji dotyczącej właśnie tego, ,jak to się skończyło”, a to już stawia pod znakiem zapytania możliwość realizacji zarówno pierwszego, jak i drugiego warunku powstania zadowalającego ujęcia historycznoliterackiego, o których wspomniałem wyżej. Należy też kategorycznie stwierdzić, że - jak dotąd - nie widać żadnych zwiastunów ewentualnej „wyprzedzającej” diagnozy. A warto pamiętać, że w żadnym wypadku skuteczną receptą na wypracowanie przewagi w rozpoznawaniu rzeczywistości nie jest „doganianie”, lecz właśnie odmienność, oryginalność takich „wyprzedzających” rozwiązań.

Poprzestańmy zatem na postulacie urozmaicenia refleksji badawczej. Mogłoby się ono dokonać - paradoksalnie - przez wprowadzenie szerszej perspektywy historycznej do opisu współczesności, co z kolei dawałoby wytchnienie wszystkim ,,autorom-tłumaczom”, pracowicie przekładającym teksty z języka polskiej literatury na język prawidłowości procesów społecznych i w związku z tym pozostawiających na marginesie jej spore obszary. Mam tu na myśli przede wszystkim podkreślanie umowności cezury roku 1989 i rzetelne, gruntowne opisanie tego, co nowoczesne i ponowoczesne, skoro nie potrafimy funkcjonować poza obszarem wyznaczonym przez nazwy tych dwóch formacji.

Raz jeszcze odwołajmy się do wywodu badacza próbującego nazwać przedmiot własnego zainteresowania i piszącego o „sztuce najnowszej” w ten sposób:

Określenie to - wymienne z (równie nieprecyzyjnym) określeniem „literatura po roku 1989" - stosuję w odniesieniu do zjawisk i procesów, które za sprawą upadku PRL-u (i jego kulturalnej infrastruktury) uległy przyspieszeniu lub intensyfikacji, w mniejszym zaś zakresie - zainicjowaniu. Najsilniejsze po roku 1989 przemiany życia literackiego wzmocniły wcześniej już przebiegające przemiany światopoglądowe i estetyczno-formalne. W tym sensie rok 1989 nie jest ostrą cezurą w dziejach polskiej literatury, choć stworzone wówczas warunki zmian, a także rozległe przekształcenia komunikacji społecznej, sprzyjają innowacjom (i uzasadniają poszukiwanie różnic $)^{21}$.

Gdybyśmy natomiast spróbowali opisać to, co „najnowsze”, bardzo „konserwatywnie", niemal wyłącznie od strony procesów wewnątrzliterackich, musielibyśmy wyznaczyć inną cezurę. Jeśli w przypadku początków polskiej nowoczesności intuicje, a później ustalenia badawcze szły w kierunku zignorowania cezury roku 1918, a przynajmniej osłabienia jej symbolicznego potencjału, to nie ma powodu, by u jej domniemanego końca (ewentualnie początku formacji, której nazwać nie potrafimy) trzymać się kurczowo innej symbolicznej daty. Tym bardziej że - jak pisał Uniłowski, w odniesieniu do lat

21 P. Czapliński, Resztki nowoczesności. Dwa studia o literaturze i życiu, Kraków 2011, s. 6. 
dziewięćdziesiątych - „każdy nurt, każde ponadindywidualne zjawisko w dzisiejszej młodej poezji i prozie ma swoją antycypację, jeśli nie odpowiednik, w poprzedniej dekadzie"22. Nie dyskutuję tu ze słusznością tej zdecydowanej diagnozy, bardziej istotne jest wskazanie ciągłości w stosunku do lat osiemdziesiątych. Inną proponowaną cezurą jest rok $1976^{23}$, z zastrzeżeniem, że data ta ma charakter orientacyjny, a „każda periodyzacyjna decyzja jest ryzykowna, naznaczona arbitralnością i wyrzutami historycznoliterackiego sumienia"24.

Właśnie ta „orientacyjność" mogłaby być punktem wyjścia i pozwalałaby na rezygnację z konkretnej daty, pod warunkiem, że początkiem okresu „przejściowego" lub literatury „nowej” uczynilibyśmy całą dekadę lat siedemdziesiątych. Nie rozwijam tu szczegółowo takiego założenia, poprzestając jedynie na konstatacji dotyczącej wyraźnych sygnałów wyczerpywania się dojrzałej postaci modernizmu w Polsce, w bólach odbudowującej swój potencjał (w literaturze krajowej) po roku 1956 i ufundowanej w dużej mierze na nawiązaniach do wypracowanych w Dwudziestoleciu poetyk i ich modyfikacjach. W tym sensie na przykład dokonana niegdyś przez Janusza Sławińskiego w Próbie porządkowania doświadczeń taksonomia zjawisk poetyckich z lat 1956-1980, choć schematyzująca, była trafna w kontekście wskazania kluczowych modeli nowoczesnego wiersza, które jednakże, po debiucie poetów Nowej Fali, coraz słabiej mieszczących się w obrębie wzorca lingwistycznego i - co ważne - niemieszczących się bez reszty w obrębie doraźności, „wspólnej sprawy” i poezji zaangażowanej, ulegały wyraźnej erozji. Nie da się pomyśleć literatury debiutantów lat dziewięćdziesiątych bez uwzględnienia swoistej kontaminacji dwóch dyskursów „kryzysowych”: tego ze Świata nie przedstawionego i tego z Bez autorytetu, książki wydanej w roku 1981; dyskursów krytycznych, znajdujących mniej lub bardziej wierne przełożenie na język utworów nie tylko poetyckich. Mówiąc o początkach „zmiany”, powinniśmy ponadto pamiętać, że procesy zapoczątkowane u progu lat siedemdziesiątych nie przebiegały linearnie, raczej miały charakter fluktuacyjny, czego doskonałym przykładem (by nie rozbudowywać zbytnio tych rozważań) są drogi twórcze Juliana Kornhausera i Bohdana Zadury, które zbiegają się na przełomie lat siedemdziesiątych i osiemdziesiątych, by potem rozejść się $\mathrm{w}$ różne strony, przybrawszy w przypadku tego pierwszego bardziej paseistyczny wymiar, zaś w przypadku drugiego - inspirujący nowe poszukiwania twórcze, choć to w wierszach Kornhausera $\mathrm{z}$ lat siedemdziesiątych pojawiają się oznaki porzucenia nowoczesnych ograniczeń. Dotyczy to zresztą większości czołowych poetów Nowej Fali. Dialog podejmowany w ciągu ostatniego

22 K. Uniłowski, op.cit., s. 23.

23 Zob. A. Nasiłowska, Literatura okresu przejściowego 1976-1996, Warszawa 2006; P. Czapliński, P. Śliwiński, Literatura polska 1976-1998. Przewodnik po prozie i poezji, Kraków 2000.

24 P. Czapliński, P. Śliwiński, op.cit., s. 7. 
trzydziestolecia z poetami tej generacji i nieco od nich młodszymi przedstawicielami Nowych Roczników, modyfikującymi (lecz nieprzekreślającymi) zbyt wychylony w stronę zbiorowości modus operandi poezji ósmej dekady jest istotnym elementem charakteryzującym to, co „nowe” lub „przejściowe”25. Co ciekawe, nie da się tego dialogu sprowadzić wyłącznie ani do polemicznych wycieczek, ani do prób powielenia chwytów „poetyki zaangażowania”. Istotność oddziaływania obu grup polega bowiem na problematyzacji samego statusu bytowego rzeczywistości i wiersza, a także zagadnienia podmiotowości. Dlatego nie dziwią w tym kontekście uwagi krytyków młodego pokolenia widzących wiersze współczesnych debiutantów przez pryzmat badania „,przydatności poetyckich strategii Nowej Fali" ${ }^{26}$ przefiltrowanych przez lekturę „okołobrulionowych" poetów.

Można więc powiedzieć, że już u progu lat osiemdziesiątych poeci zaczęli dysponować narzędziami pozwalającymi, jeśli nie na zaproponowanie nowych języków, to na świadomą negację języków obowiązujących. Jednak chcąc napisać historię literatury (w świetle poczynionych uwag: już niemal półwiecza), musielibyśmy ułożyć ją niejako w trzy pasma: ilustrujące proces klarowania się tychże nowych języków, ilustrujące procesy nawrotu do konwencji wypracowanych przez (z braku lepszego używam terminu, jak myślę, nieadekwatnego do polskich warunków) wysoki modernizm i ilustrujące procesy kontynuacji - odnoszące się do najstarszych pokoleń. A jako że w interesującym mnie okresie mieliśmy także do czynienia z zamysłami niemieszczącymi się w obrębie żadnego $\mathrm{z}$ tych trzech pasm, zadanie wydaje się (i ze względu na ogrom materiału i postulowane skomplikowanie czy subtelność wywodu związane dodatkowo z nakładaniem się na siebie przeciwstawnych, wydawałoby się, rozwiązań) co najmniej trudno wykonalne.

Wspomniałem tu o „literaturze”, bo diagnozy dotyczące dialogu propozycji artystycznych pojawiających się po roku 1989 z osiągnięciami ósmej i dziewiątej dekady XX wieku dotyczą również prozy, dla której kluczowym - jak myślę - doświadczeniem jest moment problematyzacji konwencji nowoczesności, którą przeprowadzono w powieściach i opowiadaniach autorów generacji nowofalowej i ponowofalowej, a szczególnie w kręgu „nowej prozy”,

25 Szerzej na temat tego dialogu, jak też na temat momentów kiełkowania nowych tendencji poetyckich piszę w szkicach z drugiej części książki Osiemdziesiąt. Studium o poezji „,przełomów”, Lublin 2020, a także w szkicu Julian Kornhauser czy Frank O'Hara? Kilka uwag o prekursorstwie $i$,postmodernizmie” [w:] Rzeczy do nazwania. Wokót Kornhausera, red. A. Gleń, J. Kornhauser, Poznań 2016. O symulacyjnym charakterze poetyki Nowej Fali i oznakach pre-postmodernistycznego przesilenia, zob. A. Niewiadomski, Światy z jawnych słów i kwiatów ukrytych. O refleksji metapoetyckiej w nowoczesnej poezji polskiej, Lublin 2010 (rozdz. Nowa Fala: prawda poezji, prawda języka, prawda ,zmienionej skóry” świata, czyli... poetyka pozoru).

26 M. Koronkiewicz, Kult cargo i brzydkie wyrazy [w:] P. Kaczmarski, M. Koronkiewicz, Zebrało się śliny, s. 98. 
nazywanej też „prozą rewolucji artystycznej”. Dysponujemy przecież całkiem już licznymi ustaleniami badawczymi, także tymi najnowszymi, wskazującymi na moment wyczerpywania się modernistycznych zagadnień i na jaskółki polskiego postmodernizmu pojawiające się na długo przed przyjmowaną mechanicznie, graniczną datą domniemanego „przełomu”27. Jeśli nie mówimy w związku z tym o wyraźnej cezurze, to tylko dlatego, że wkracza w ów obszar rozważań przywołana już „późna nowoczesność” jako inna nazwa „okresu przejściowego". Problemy natomiast pozostają te same, włącznie z próbami wywikłania się z biegunów autonomii i zaangażowania czy wątpliwościami dotyczącymi dyskursu tożsamościowego (indywidualnego i pokoleniowego). Nie dziwi więc stwierdzenie, że:

[...] wczesne powieści Stefana Chwina (jako Maxa Larsa) oraz Weiser Dawidek Pawła Huelle były zaskakująco podobne do „bajkopisarstwa” Słyka i Ulmana. Dorota Masłowska, Michał Witkowski czy Sławomir Shuty snuli opowieści zbliżone do narracji o codzienności Schuberta czy Pluty, eksponując dyskursywny, retoryczny charakter codziennej egzystencji. W ogóle sfera problematyki tożsamościowej istotna w pisarstwie „roczników siedemdziesiątych” wydaje się ponowieniem tego, co zajmowało autorów narracji biograficzno-pokoleniowych „nowej prozy" ${ }^{\prime 28}$.

Zauważmy też, że właśnie w latach siedemdziesiątych pojawia się pewnego rodzaju bezradność terminologiczna: Nowa Fala i nowa proza zostają opatrzone epitetem, który i dziś - z braku innych propozycji - ma definiować literaturę po roku 1989, a który, paradoksalnie, wciąż podawany jest w wątpliwość ze względu na dyskusyjny status samej nowości jako kryterium określającego wartość tekstu. I do tego obrazu dorzućmy jeszcze równie nieustabilizowany jak w przypadku poezji i prozy obraz dramatu ostatniej dekady XX wieku, w której - zdaniem autora jednej z antologii - najciekawsze utwory „napisali autorzy należący do co najmniej trzech pokoleń” ${ }^{29}$, dziesięciolecie to nie przyniosło „zasadniczej zmiany w poetyce tekstu dramatycznego" ${ }^{30}$, zaś podsumowanie tego, co wydarzyło się w uznawanym powszechnie za „przełomowy” okresie, wypada raczej jako diagnoza stanu przejściowego: „Sztuki ostatniej dekady XX wieku na różny [...] sposób oży-

27 Najbardziej klarowną wersję takiego rozumowania przedstawił K. Uniłowski w książkach Polska proza innowacyjna w perspektywie postmodernizmu, Katowice 1999 i Granice nowoczesności. Polska proza i wyczerpanie modernizmu, Katowice 2006.

28 P. Kaliszuk, Wyczerpywanie i odnowa. „Nowa” polska proza lat siedemdziesiatych i osiemdziesiątych wobec późnej nowoczesności, Lublin 2019, s. 342.

29 J. Kopciński, Przejście. Dramaturgia końca XX wieku [w:] Trans/formacja. Dramat polski po 1989 roku. Antologia, wybór i wstęp J. Kopciński, Warszawa 2012, s. 8.

30 Ibidem, s. 13. 
wiają dramatyczny wzór niepełnego końca i niejasnego początku i fabularyzują sytuację życia pomiędzy"31.

Zasadniczy problem związany $\mathrm{z}$ wytworzeniem takiej solidnej narracji historycznoliterackiej opisującej ostatnie półwiecze leży właśnie w nieobecności czynnika w sposób bezdyskusyjny uprawomocniającego zmianę. Nawet jeśli przyjmiemy, że nie gest radykalnego zerwania stanowił jej początek, lecz narastająca obojętność wobec „wielkich” problemów nowoczesności, ta rodem z Dla Jana Polkowskiego, czy z komentowanej swego czasu (choć nie tak obszernie) prozy poetyckiej Zadury:

Całe życie marzyliśmy o tym, by stanąć obok nich, a po ich najdłuższym panowaniu zająć ich miejsce. I oto przestaliśmy ich czytać: kiedy wtajemniczeni są wszyscy, nie ma tajemnicy. Królestwo zniknęło wraz z imperium, jakby go nigdy nie było. Mieliśmy szczęście: nie zdążyliśmy objąć sukcesji32.

Zauważmy, że jeżeli Marcin Świetlicki przemawiał wyłącznie we „własnym" imieniu, to Zadura czynił to, biorąc pod uwagę perspektywę jakiejś zbiorowości autorów abstrahujących od hierarchii zrodzonych w kręgu polskiego „wysokiego modernizmu”. Rzecz w tym, czy jest to zbiorowość reprezentatywna dla złożoności procesów zachodzących w „,nowej literaturze”, a jeszcze istotniejsza wydaje się sprawa nieobjęcia sukcesji. Nieprzypadkowo chyba w jednej z prac dotyczących „nowej prozy” to właśnie debiutancka powieść Zadury stanowi chronologicznie pierwszą pozycję w ciągu rozważańn ${ }^{33}$. Chodzi o to, że deklarowana obojętność jest raczej nieustannym namysłem oraz wahaniem, czy z dawnego władztwa można i warto jednak coś dla siebie uszczknąć, nie mówiąc już o nieustającej wojnie z tymi, którzy wciąż uważają się za dziedziców korony. Jest to zarazem walka o uznanie jednego z nurtów literatury ostatniego półwiecza za nurt dominujący, czyli właśnie między innymi o wykluczenie „konserwatywnej” narracji całościowej, która - choć nieosiągalna - powinna w swojej potencjalności, jak wspomniałem, spełniać funkcję lustra odbijającego „lokalne” koncepty i diagnozy cząstkowe, nieroszczące sobie prawa do totalizującego ujęcia. Poza wszystkim należałoby też stwierdzić, że siła ciążenia tradycyjnych mechanizmów następstwa jest wciąż duża; wielu spośród najmłodszych twórców urodzonych w latach osiemdziesiątych XX wieku, wszystko na to wskazuje, zaczęło bowiem traktować tych,

31 Ibidem, s. 32. Trzeba jednak dodać, że tak jak w przypadku poezji i prozy badacz odnotowuje obecność w dramacie po roku 1989 nowych tendencji związanych choćby $\mathrm{z}$ „recepcją nowego dramatu niemieckiego i angielskiego” oraz „estetyką performatywności" i teorią teatru postdramatycznego (zob. ibidem, s. 13).

32 B. Zadura, Wycofuję się z życia; koniec świata [w:] idem, Wiersze wybrane, Poznań 2011, s. 267.

33 P. Kaliszuk, op.cit. 
którzy teoretycznie wzbraniali się przed przejęciem schedy po klasykach nowoczesności, jako niekoronowanych władców literackiego parnasu, co z kolei uniemożliwia nam rozprawianie zarówno o końcu dużej, jak i o końcu małych historycznoliterackich opowieści, odnoszących się do wspomnianego półwiecza.

Jeżeli zatem mamy do czynienia z materią tak skomplikowaną, że nie sposób mówić o klarownych ujęciach całościowych, innym wyjściem byłaby radykalizacja cząstkowych dyskursów krytycznych i badawczych. Polegałaby ona na zintensyfikowaniu działań zmierzających do zdefiniowania preferencji estetycznych i próbie rzetelnej wiwisekcji dorobku autorów wpisujących się w te preferencje, wychodzącej poza pojedyncze analizy. Kontrowersyjność takiej strategii osłabiona byłaby przez ewentualną wielość różnych, często skrajnych, ujęć. Wiązałoby się to także z ożywieniem dyskusji i z konfrontacją odmiennych języków, opartych na przeciwstawnych aksjologiach. Takie założenie w dzisiejszych warunkach życia literackiego ma, oczywiście, charakter czysto teoretyczny. Jego realizacja wymagałaby bowiem „oczyszczenia przedpola", czyli niemożliwego w praktyce wyzerowania hierarchii i dopiero w dalszej kolejności argumentacji uzasadniającej wybór takiej, a nie innej strategii pisarskiej jako „poetyki” odpowiadającej na wyzwania współczesności (bądź, co także możliwe, zupełnie je ignorującej). Warto jednak pamiętać przy tym, że zderzenie stanowisk musiałoby się wiązać z ożywieniem dyskusji nie na skalę niegdysiejszych sporów prowadzących ku ślepej uliczce biegunowego ujmowania literatury, lecz powodowałoby jednoczesne wyjście na powierzchnię zniuansowanych dyskursów niepodlegającym ideologicznemu zawłaszczeniu. A jako że jesteśmy na etapie coraz szybciej postępującej ideologizacji, nadzieje na ziszczenie się takiego scenariusza są równie płonne jak wypatrywanie opasłej historii literatury półwiecza, uwzględniającej niemal wszystkie ważniejsze jej przejawy.

Pozostaniemy więc zapewne przez czas jakiś w kontekście funkcjonowania niewypowiedzianego kanonu, hierarchii nieoczywistej tylko dlatego, że wszelka oczywistość grozi uwikłaniem w represyjne dyskursy, a samo pojęcie kanonu dawno stało się problematyczne. Może warto jednak zarysować pokrótce wyobrażone alternatywy, choćby tylko po to, by nieco nadkruszyć dobre samopoczucie krytyki deklarującej dynamiczne podejście do pola literatury współczesnej i zdradzającej tendencję do zastygnięcia w kręgu tego dogmatu, który wstydliwie zakrywa obraz, co by nie mówić, dość stabilnych, choć niewystarczająco zdefiniowanych, preferencji. 


\section{Bibliografia}

Artwińska A., Fidelis M., Mrozik A., Zawadzka A., Pożytki z „,pokolenia”. Dyskusja o ,pokoleniu” jako kategorii analitycznej, „Teksty Drugie” 2016, nr 1.

Bolecki W., Polowanie na postmodernistów (w Polsce), Kraków 1999.

Była sobie krytyka. Wybór tekstów z lat dziewięćdziesiatych i pierwszych, oprac. i wstęp D. Nowacki, K. Uniłowski, Katowice 2003.

Czapliński P., Polska do wymiany. Późna nowoczesność i nasze wielkie narracje, Warszawa 2009.

Czapliński P., Resztki nowoczesności. Dwa studia o literaturze i życiu, Kraków 2011.

Czapliński P., Śliwiński P., Literatura polska 1976-1998. Przewodnik po prozie i poezji, Kraków 2000.

Dwadzieścia lat literatury polskiej 1989-2009. Idee, ideologie, metodologie, red. A. Galant, I. Iwasiów, Szczecin 2008.

Dwadzieścia lat literatury polskiej 1989-2009, t. 1, cz. 1: Życie literackie po roku 1989, red. D. Nowacki, K. Uniłowski, Katowice 2010.

Dwadzieścia lat literatury polskiej 1989-2009, t. 1, cz. 2: Życie literackie po roku 1989, red. D. Nowacki, K. Uniłowski, Katowice 2011.

Kaczmarski P., Koronkiewicz M., Zebrało się śliny, Stronie Śląskie 2006.

Kaliszuk P., Wyczerpywanie i odnowa. „Nowa” polska proza lat siedemdziesiatych i osiemdziesiatych wobec późnej nowoczesności, Lublin 2019.

Kisiel M., Jak możliwa jest synteza literatury polskiej po 1989 roku? [w:] Inna literatura. Dwudziestolecie 1989-2009, t. 1, red. Z. Andres, J. Pasterski, Rzeszów 2010.

Klejnocki J., Sosnowski J., Chwilowe zawieszenie broni. O twórczości tzw. pokolenia „, bruLionu” 1986-1996, Warszawa 1996.

Kopciński J., Przejście. Dramaturgia końca XX wieku [w:] Trans/formacja. Dramat polski po 1989 roku. Antologia, wybór i wstęp J. Kopciński, Warszawa 2012.

Marecki P., Stokfiszewski I., Witkowski M., Tekstylia. O rocznikach siedemdziesiatych, Kraków 2002.

Nasiłowska A., Literatura okresu przejściowego 1976-1996, Warszawa 2006.

Niewiadomski A., Dwudziestolecie versus dwudziestolecie. O przypadkach poezji najnowszej z perspektywy historyka literatury, „Teksty Drugie” 2013, nr 3.

Niewiadomski A., Julian Kornhauser czy Frank O'Hara? Kilka uwag o prekursorstwie i „postmodernizmie” [w:] Rzeczy do nazwania. Wokół Kornhausera, red. A. Gleń, J. Kornhauser, Poznań 2016.

Niewiadomski A., Osiemdziesiąt. Studium o poezji „,przełomów”, Lublin 2020.

Niewiadomski A., Światy z jawnych stów i kwiatów ukrytych. O refleksji metapoetyckiej w nowoczesnej poezji polskiej, Lublin 2010.

Nowe dwudziestolecie. 1989-2009. Rozpoznania - hierarchie - perspektywy, red. H. Gosk, Warszawa 2010.

Nowe dwudziestolecie. Szkice o wartościach i poetykach prozy i poezji lat 1989-2009, red. P. Śliwiński, Poznań 2011.

Orska J., Liryczne narracje. Nowe tendencje w poezji polskiej 1989-2006, Kraków 2006. 
Orska J., Republika poetów. Poetyckość i polityczność w krytycznej praktyce, Kraków 2013.

Śliwiński P., Przygody z wolnością. Uwagi o poezji współczesnej, Kraków 2002.

Świeściak A., Melancholia w poezji polskiej po 1989 roku, Kraków 2011.

Uniłowski K., Granice nowoczesności. Polska proza $i$ wyczerpanie modernizmu, Katowice 2006.

Uniłowski K., Polska proza innowacyjna w perspektywie postmodernizmu, Katowice 1999.

Uniłowski K., Skądinąd, Bytom 1998.

Walas T., Czy jest możliwa inna historia literatury, Kraków 1993.

Wyka K., Pokolenia literackie, Kraków 1977.

Zadura B., Wiersze wybrane, Poznań 2011. 